Document downloaded from:

http://hdl.handle.net/10251/73780

This paper must be cited as:

Mariela Beatriz; Borrás Falomir, L.; Seco Torrecillas, A.; Ferrer, J. (2015). Identification and quantification of microbial populations in activated sludge and anaerobic digestion processes. Environmental Technology. 36(1):45-53. doi:10.1080/09593330.2014.934745.

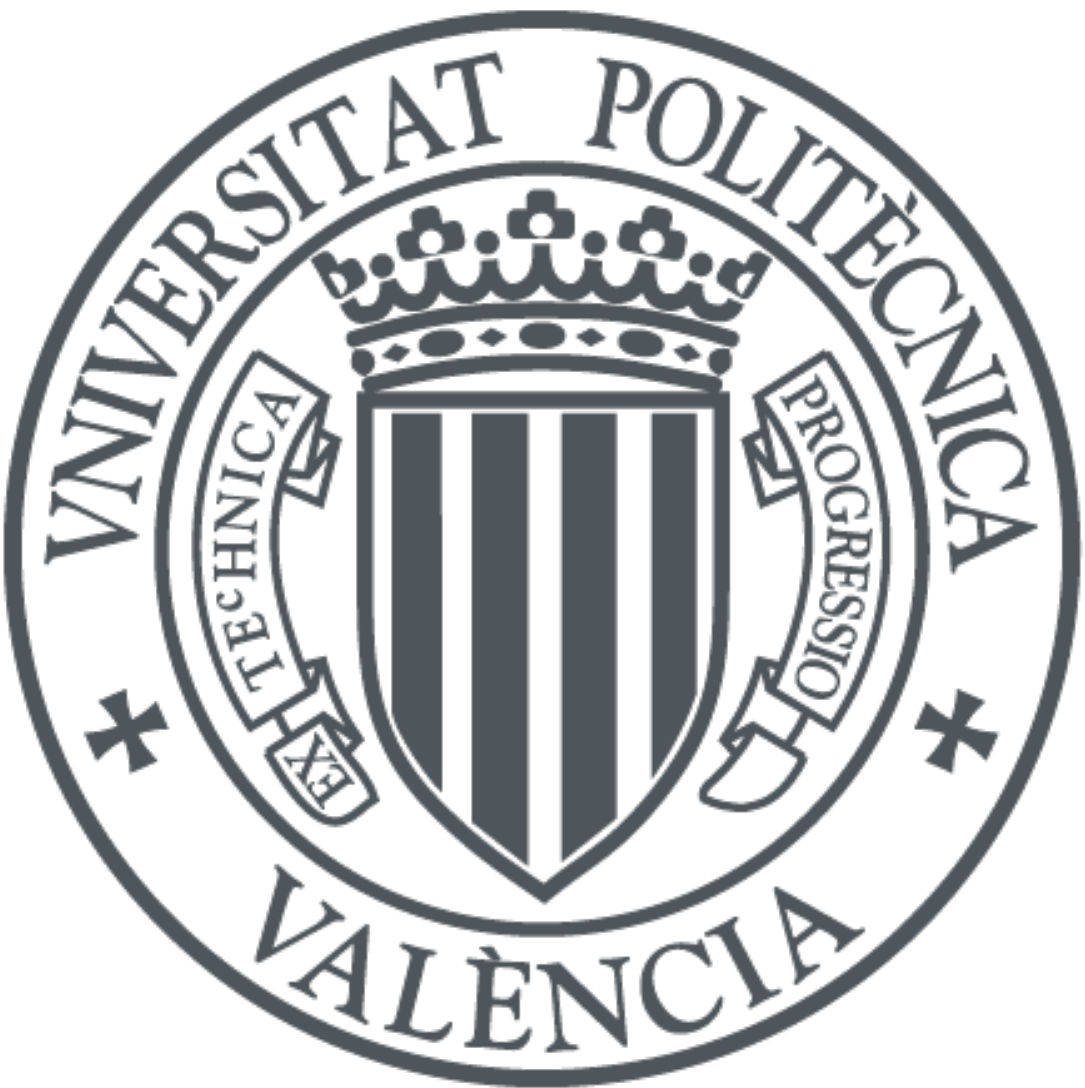

The final publication is available at

http://dx.doi.org/10.1080/09593330.2014.934745

Copyright Taylor \& Francis

Additional Information 


\section{Identification and quantification of microbial populations in activated sludge and anaerobic digestion processes}

M. Reyes ${ }^{\mathrm{a}}$, L. Borrás ${ }^{\mathrm{b}^{*}}$, A. Seco ${ }^{\mathrm{b}}$, J. Ferrer ${ }^{\mathrm{a}}$

${ }^{a}$ Instituto de Ingeniería del Agua y Medio Ambiente, Universidad Politécnica de Valencia,Valencia,Spain.(mareso@posgrado.upv.es,jferrer@hma.upv.es)

${ }^{b}$ Departamento de Ingeniería Química, Universitat de València, Burjassot, Spain. (luis.borras-falomir@uv.es,aurora.seco@uv.es)

*corresponding author. Present address: Universitat de Vàlencia, Avda. de la Universidad s/n, 46100 Burjasot Spain. Phone 0034 963543731. E-mail: luis.borrasfalomir@uv.es 


\section{Identification and quantification of microbial populations in activated sludge and anaerobic digestion processes}

Eight different phenotypes were studied in an activated sludge process (AeR) and anaerobic digester (AnD) in a full-scale WWTP by means of fluorescent in situ hybridization (FISH) and automated FISH quantification software. The phenotypes were: ammonia-oxidizing bacteria (AOB), nitrite-oxidizing bacteria (NOB), denitrifying bacteria, phosphate-accumulating organisms (PAO), glycogen-accumulating organisms (GAO), sulfate-reducing bacteria (SRB), methanotrophic bacteria and methanogenic archaea. Some findings were unexpected: (a) Presence of PAO, GAO and denitrifiers in the AeR possibly due to unexpected environmental conditions caused by oxygen deficiencies or its ability to survive aerobically; (b) Presence of SRB in the AeR due to high sulfate content of wastewater intake and possibly also due to digested sludge being recycled back into the primary clarifier; (c) Presence of methanogenic archaea in the AeR, which can be explained by the recirculation of digested sludge and its ability to survive periods of high oxygen levels; (d) Presence of denitrifying bacteria in the AnD which cannot be fully explained because the nitrate level in the AnD was not measured. However, other authors reported the existence of denitrifiers in environments where nitrate or oxygen was not present suggesting that denitrifiers can survive in nitrate-free anaerobic environments by carrying out low-level fermentation; (e) The results of this paper are relevant because focus on the identification of nearly all the significant bacterial and archaeal groups of microorganisms with a known phenotype involved in the biological wastewater treatment.

Keywords: microbial diversity, FISH, phenotype, activated sludge, anaerobic digester

\section{Introduction}

The heart of a wastewater treatment plant (WWTP) is a dense microbial consortium in which organic and nutrient contaminants are removed, mainly by bacteria and archaea. There is, therefore, great interest in identifying the structure of this consortium and the 
functions of the groups of bacteria and archaea it is composed of.

Many studies have investigated the diversity of microbial populations. Such studies now increasingly use molecular techniques that do not need the microorganisms to be isolated or cultivated, e.g. $16 \mathrm{~S}$ rRNA analysis and fluorescence in situ hybridization (FISH). Other techniques such as microautoradiography-fluorescence in situ hybridization (MAR-FISH) have also been used to identify the bacterial community phylum level and phenotype in wastewater [1], along with other techniques such as polymerase chain reaction (PCR) combined with denaturing gradient gel electrophoresis (DGGE) [2], and pyrosequencing [3, 4]. In other words, some studies using molecular techniques have been conducted to identify the microorganisms involved in the removal of nutrients such as phosphorus $[5,6,7]$ and nitrogen $[8,9,10,11,12,13]$, whilst other studies have focused on methanogenic archaea $[14,15]$ and other phenotypes involved in wastewater treatment such as sulfate-reducing bacteria (SRB) and methanotrophic bacteria.

Most of the studies found in literature focus on one or two groups of organisms involved in the removal of nutrients, carbon, hydrogen or sulfur. The study of these bacterial or archaeal phenotypes is of great interest to engineers and microbiologists. However, no studies focus on the identification of all the important groups of microorganisms (i.e. those with a known phenotype) involved in wastewater treatment.

Given the need to identify the different groups of microorganisms and understand their roles and interactions in the wastewater treatment processes, new studies are continuously being developed to investigate bacterial and archaeal phenotypes such as:

- Ammonia oxidizing bacteria (AOB) and nitrate oxidizing bacteria (NOB): the chemolithoautotrophic bacteria responsible for nitrification. 
- Denitrifying bacteria, many of which are heterotrophic and need organic matter for their energy and carbon supply [16].

- Polyphosphate accumulating organisms (PAOs), which participate in the removal of phosphorus and its competing bacteria: glycogen accumulating organisms (GAOs). PAOs and GAOs are found in enhanced biological phosphorus removal (EBPR) plants.

- Sulfate-reducing bacteria (SRB) which are involved in the sulfur cycle and are present in many activated sludge systems [17]. SRB are physiologically active for extended periods in sludge storage tanks [18] and can grow in the drainage channels of these tanks. They are then transported to the WWTP where they proliferate under anaerobic conditions [19].

- Organisms that participate in the hydrogen and carbon cycles, such as methanotrophic bacteria and methanogenic archaea. Methanogenic archaea are difficult to cultivate which is why our understanding of them is limited. They have, however, been successfully isolated in anaerobic digesters. These organisms, characterized by their slow growth rate, are assumed to be strictly anaerobic [20] but some studies [21, 22] concluded that methanogenic archaea can be detected in anoxic or aerobic microhabitats within floccules in activated sludge $[23,24]$. The role played by methanogenic archaea in these processes has not been studied thoroughly [22].

Considering the above mentioned phenotypes and the importance of studying them all within the microbial population, the aim of this study is to identify and quantify the main bacteria and archaea (phenotypes) involved in wastewater treatment, both in an activated sludge process and in an anaerobic digester in a full-scale WWTP. 


\section{Materials and Methods}

\section{Samples}

Samples were taken from a WWTP treating $38500 \mathrm{~m}^{3} \mathrm{~d}^{-1}$, located in Valencia, Spain. The main biological processes in the WWTP were a conventional fully aerobic activated sludge process and an anaerobic digestion process. Duplicate samples were taken from the activated sludge tank and from the anaerobic digester and then quickly transferred to the laboratory in an icebox and fixed for FISH. The temperature of the aerobic process was about $16{ }^{\circ} \mathrm{C}$ and the temperature in the digester was slightly more than $30^{\circ} \mathrm{C}$. The dissolved oxygen (DO) in the aerobic reactor was between $0.8-2 \mathrm{mg} \mathrm{l}^{-1}$. In the WWTP, the removal efficiencies of suspended solids, BOD and COD were $98 \%$, $97 \%$ and $94 \%$, respectively.

\section{Fluorescence in situ Hybridization (FISH)}

Samples were fixed in $4 \%$ paraformaldehyde at $4{ }^{\circ} \mathrm{C}$ (1-3 hours) for gram-negative organisms and in $50 \%$ ethanol at $4{ }^{\circ} \mathrm{C}$ (4-16 hours) for gram-positive. The fixed biomass was washed three times with phosphate-buffered saline (PBS), and re-suspended in a 1:1 (v/v) volume of PBS and absolute ethanol and then stored at $-20^{\circ} \mathrm{C}$. The fixed samples were immobilized on gelatin-coated glass slides, air-dried, and consecutively dehydrated in 50\%, 80\% and absolute ethanol. Hybridization buffer and probes were applied to the slide and incubated at $46{ }^{\circ} \mathrm{C}$ for 1-3 hours [25]. Excess probes were washed off by heating at $48{ }^{\circ} \mathrm{C}$ for $15 \mathrm{~min}$ in a washing buffer [25].

Table 1 shows the 34 probes used in this study plus the 5 helper/competitor probes, including 24 organisms and 8 different phenotypes. All probes were labeled with TAMRA, except EUBmix (EUB338, EUB338 II and EUB338 III) and ARCH915, which were labeled with FAM, and the competitor/helper probes which were not 
labeled. Details of oligonucleotide probes are available at probeBase [26]. The probes listed in Table 1 were all applied to the samples taken from both the aerobic reactor and the anaerobic digester.

\section{Microscopic observation and quantification}

Microscopic observation was performed using a Leica DM2500 epifluorescence microscope fitted with a Leica 420C camera. The percentage of bacteria in a specific phenotype or group was calculated by multiplying the area occupied by the specific functional group by 100 and dividing it by the area occupied by the hybridized bacteria with EUBmix plus ARCH915 probes.

A minimum of 20 images of randomly chosen microscopic fields were taken for each probe-hybridized sample.

The signals detected by FISH were quantified using automated bacteria quantification software [47] based on thresholding techniques implemented using Matlab $^{\circledR}$. The software-generated report states the percentage areas occupied by hybridized bacteria and the measurement uncertainty, i.e. the standard deviation divided by the square root of the number of fields examined. 


\section{Results}

\section{Microbial diversity in the WWTP}

FISH technique was applied in order to identify some bacterial and archaeal groups involved in the production or removal of nitrogen, phosphorus, methane and sulfate in the aerobic reactor and in the anaerobic digester. The signal obtained from all the oligonucleotide probes used in this study was strong and indicated high cellular rRNA contents.

Table 2 shows the detailed diversity of microbes found in both the activated sludge reactor and the anaerobic digester. Figure 1 shows the diversity and quantity of microbes in both systems including unidentified microorganisms.

\section{Activated Sludge Process}

The SRB was the most abundant phenotype found in the activated sludge process, comprising $27 \%$ of all detectable bacteria. This group was composed of Desulfobacteraceae (15\%) and Desulfovibrionales (12\%) hybridized with probes SRB385Db and SRB385 respectively. The second most abundant group was the denitrifying bacteria (19\% of all detectable bacteria), in which only the genera Azoarcus-Thauera identified using probe AT1458 and Paracoccus identified using probe PAR651 were detected. Methanogenic archaea was the third most abundant division in the activated sludge process (11\% of all detectable bacteria). The probes which gave positive signal within this group were MG1200b (Methanomicrobiales) and MB311 (Methanobacterales). The next group was the nitrifying bacteria group comprising $9 \%$ of all detectable bacteria. Within this group, the phenotype AOB (probe NSO1225LNA) was the most abundant nitrifying bacteria (7\% of all detectable bacteria) while the sublineage Nitrospira, detected with probe Ntspa712 (2\% of all detectable bacteria) was the only NOB detected in the aerobic reactor. Other 
microorganisms were present in the aerobic reactor with low abundances as: GAO related to the Defluvicoccus cluster 2 (4\%), detected with probes DF988 and DF1020; PAO group comprising $2 \%$ of all detectable bacteria (covering the sum of probes PAO462, PAO651, PAO846); and Methylocystaceae type 2 methanotrophic bacteria detected with the probe Ma464 (1\%).

\section{Anaerobic digestion process}

The diversity of microbes in the anaerobic digester was somewhat smaller than in the aerobic reactor. The only phenotypes found in the anaerobic digester were denitrifying bacteria, SRB and methane-forming archaea. In this case the main group was methanogenic archaea (30\% of all detectable bacteria) related with Methanomicrobiales (probe MG1200b), Methanobacterales (probe MB311) and Methanosarcinales (probe MSMX860), followed by SRB (20\% of all detectable bacteria) and denitrifying bacteria ( $10 \%$ of all detectable bacteria) related with the genera Azoarcus-Thauera (probe AT1458), Paracoccus (probe PAR651) and Thiobacillus (probe TBD1419).

It should be highlighted that the probes (see Table 2) used to identify the functional groups, allowed to identify 8 phenotypes in the aerobic reactor and 3 phenotypes in the anaerobic digester (Figure 1). Some target organisms (e.g. NOB phenotype Nitrobacter) were not detected in either the aerobic reactor or the anaerobic digester. See Table 2 for details.

The percentage of unidentified microorganisms in both processes is particularly striking: $27 \%$ in the reactor and $40 \%$ in the digester. They are assumed to be other heterotrophic bacteria together with many acidogenic / acetogenic organisms, sulfuroxidizing bacteria and non-detected archaea. 


\section{Discussion}

It must be emphasized that many microorganisms were not identified $(27 \%$ in the aerobic reactor and $40 \%$ in the anaerobic digester). These unidentified microorganisms may include other functional groups involved in the wastewater treatment process, such as acidogenic-acetogenic bacteria. However, this study is restricted to the functional groups that can be detected by FISH probes (AOB, NOB, denitrifying bacteria, PAO, GAO, methane-oxidizing bacteria, SRB and methane-forming archaea). Unfortunately not all the phenotypes in the aerobic and anaerobic processes can be identified by FISH probes. It is therefore important to develop new FISH probes in order to reduce the percentage of unidentified organisms in these processes.

The WWTP studied was not designed to remove biological nutrients, and yet denitrifying bacteria (19\%), PAO (2\%) and GAO (4\%) were detected in the activated sludge process (Figure 1). The unexpected presence of these phenotypes could be due to unforeseen environmental conditions caused by hydraulic malfunctions or poor design of the aerobic reactor, which could facilitated the existence of anaerobic or anoxic conditions. However, many denitrifying bacteria can also perform aerobic COD oxidation, evidencing that they are not exclusive denitrifiers. Azoarcus, Thauera and Paracoccus, for example, are commonly detected in aerobic PHA producing mixed microbial cultures [48]. In the same way, PAOs and GAOs have been previously observed in plants not designed for EBPR [49], suggesting that it is possible that PAO and GAO metabolism is flexible and they could survive aerobically.

Three of the microbial groups studied, i.e. denitrifying bacteria, SRB and methanogenic archaea, were detected in both processes (Figure 1). SRB and methanogenic archaea were not expected to be found in the aerobic reactor while 
denitrifying bacteria were not expected to be found in the anaerobic digester. Possible reasons for the presence of these organisms are discussed below.

Denitrifying bacteria can grow under different substrates with low molecular weight in the presence of $\mathrm{NO}_{2}^{-}$or $\mathrm{NO}_{3}^{-}$. Some bacteria in this group use compounds such as $\mathrm{S}^{2-}, \mathrm{S}^{0}, \mathrm{~S}_{2} \mathrm{O}_{3}{ }^{2-}, \mathrm{S}_{4} \mathrm{O}_{6}{ }^{2-}$ and $\mathrm{SO}_{3}{ }^{2-}$ instead of organic compounds to carry out nitrate reduction and are known as autotrophic denitrifying bacteria $[50,51]$. However, the bacterial community involved in the biological autotrophic denitrification process of raw sewage is not fully understood due to a lack of knowledge about the responsible bacteria and the factors governing the process [51].

The denitrifying bacteria (19\% of the total biomass in the aerobic reactor and $10 \%$ in the digester) found in this study (Azoarcus-Thaurea, Paracoccus and Thiobacillus denitrificans) differ. For example, Azoarcus and Thauera feature a wide range of short-chain fatty acids and amino acids [52], which makes it easy to find these organisms in a variety of systems. The level of Azoarcus-Thauera (probe AT1458) found in the aerobic reactor in this study was $15 \%$. This result is in line with other results found in the reactors of full-scale plants, where Azoarcus accounts for 3-16\% of total biomass [53] while Thaurea accounts for $2-11 \%$ of the total biomass [53] in fullscale plants. In our study the Azoarcus-Thauera cluster accounted for $3 \%$ of the total biomass in the anaerobic digester.

Paracoccus can grow under different concentrations of DO, using $\mathrm{N}$-oxides as electron acceptors and a variety of carbon sources including amines and alcohols [54]. Most Paracoccus species can use nitrate and its reduction products as an alternative electron acceptor to oxygen during anoxic respiratory growth [54]. Paracoccus denitrificans can grow in aerobic, low oxygen or anaerobic conditions and can also use sulfur compounds (such as thiosulfate) as electron donors in denitrification [51]. Its 
ability to use different electron donors makes it possible to find these bacteria in aerobic and anoxic conditions with nitrate, nitrite or nitrous oxide as the terminal electrons acceptor [54]. Paracoccus denitrificans can survive in ecosystems with fluctuating aerobic or anoxic conditions. Paracoccus levels in this study were $4 \%$ and $3 \%$ in the aerobic reactor and anaerobic digester respectively.

Thiobacillus denitrificans is mainly characterized by its ability to grow as a facultative anaerobic and chemolithoautotroph microorganism [56]. This organism can carry out denitrification and sulfur oxidation. In denitrification, Thiobacillus may use sulfur compounds and nitrate, nitrite or nitrous oxide as terminal respiratory oxidants, but the sulfur oxidizing enzymes involved in aerobic or anaerobic conditions are still unknown. Moreover, the optimal temperature for the growth of Thiobacillus is 28 to 32 ${ }^{\circ} \mathrm{C}$ with a $\mathrm{pH}$ of 6 to $7.4[56,57]$, i.e. the temperature range found in the anaerobic digester studied.

Azoarcus, Thauera, Paracoccus and Thiobacillus can grow in aerobic and anoxic conditions. As mentioned earlier, Azoarcus, Thauera, Paracoccus and Thiobacillus can use different substrates, but they all need nitrates or nitrites as electron acceptors. In the case of Azoarcus, Thauera and Paracoccus they can also use oxygen as electron acceptor [48]. Nitrates were detected in the aerobic reactor (data not showed) which explains the presence of Azoarcus-Thauera and Paracoccus in it. However Thiobacillus was not detected in the aerobic reactor. This is because its optimal temperature is higher than the aerobic reactor temperature (about $16{ }^{\circ} \mathrm{C}$ ). As nitrates were not measured in the anaerobic digester (none were expected to be found there) the presence of denitrifying bacteria in it is not fully understood, but other authors reported the existence of denitrifiers in environments where nitrate or oxygen was not present for long periods of time which suggests that denitrifiers can survive in nitrate- 
free anaerobic environments by carrying out low-level fermentation $[58,59]$. A detailed study of the metabolism of this microorganism is required in order to explain the results obtained.

The second largest group of bacteria detected in both processes was SRB. Although SRB has traditionally been considered to be strictly anaerobic, in recent years sulfate-reducing activity in aerobic environments has been reported, revealing a wide ecological range of SRB [60]. In our study, high levels of SRB (Desulfobacteriaceae and Desulfovibrionales) were found in both systems (27\% in the aerobic reactor and $20 \%$ in the anaerobic digester).

In the WWTP under study, sludge from the anaerobic digester is recycled back into the primary clarifier because of sludge disposal problems. This could be one of the reasons why sulfate-reducing bacteria were detected in the aerobic reactor. Moreover, the wastewater intake was rich in sulfates due to soil characteristics. This provides sulfates for SRB growth. On the other hand, there are two possible sulfate reactions: the biological transformation of sulfate into sulfide, and the chemical oxidation of sulfides to form sulfates by means of constant aeration. This chemical reaction provides an almost unlimited source of sulfates.

Desulfobacteriaceae, the largest group of SRB in the aerobic reactor (15\%), use $\mathrm{SO}_{4}, \mathrm{O}_{2}$, and $\mathrm{NO}_{3}$ as terminal electron acceptors [61] to oxidize $\mathrm{H}_{2}$ and organic compounds, including acetate. The ability of this SRB group to use acetate in oxic and anoxic conditions may explain its high levels in the aerobic reactor.

Similar observations about the presence of Desulfovibrionales $(12 \%$ in the aerobic reactor) in oxic environments have been made in the literature $[62,63,64]$. Two studies $[65,66]$ found that the Desulfovibrio species was the main SRB in an aerobic 
wastewater biofilm, which emphasizes their ability to survive in the presence of oxygen [67].

Methanogenic archaea is the third group of organisms present in both processes (11\% in the aerobic reactor and $30 \%$ in the anaerobic digester). These organisms are true anaerobes and therefore not expected to be found in the aerobic reactor. However, large numbers of methanogenic organisms have been found in various activated sludge treatment plants $[68,69]$. Specifically, the same methanogenic orders (methanomicrobiales and methanobacterales) found in the present work have been found in low dissolved oxygen level $(0.5-0.8 \mathrm{mg} / \mathrm{l})$ activated sludge processes by other authors [22].

However, the methanogenic archaea found in the samples was probably due, as mentioned above, to sludge from the anaerobic digester being pumped back into the primary clarifier. It has been reported that methanogens in aerated sludges may simply be able to survive high oxygen levels but are inactive until reducing conditions are established [22]. A decrease of approximately $60 \%$ in methanogenic archaea levels was observed between the anaerobic digester and the aerobic reactor. This could mean that the methanogenic archaea were disappearing, but that the cell retention time in the aerobic reactor was not low enough to enable them to disappear completely.

\section{Conclusions}

As a general conclusion, in a WWTP it is possible to find non-expected microorganisms in a specific process (e.g. SRB and methanogenic archaea in the activated sludge process or denitrifying bacteria in the anaerobic digester) due to the interconnection of the processes and to the metabolic flexibility of the microorganisms. 


\section{Acknowledgements}

This study was realized with support from the Universitat Politècnica de València, Universitat de València and CONACYT (National Council of Science and Technology of Mexico).

\section{References}

[1] Thayanukul P, Zang K, Janhon T, Kurisu F, Kasuga I, Furumai H. Concentrationdependent response of estrone-degrading bacteria community in activated sludge analyzed by microautoradiography-fluorescence in situ hybridization. Water Res. 2010; 44: 4878-4887.

[2] Liu Y Q, Kong Y H, Zhang R, Zhang X, Wong F S, Tay J H, Zhu J R, Jiang WJ, Liu W T. Microbial population dynamics of granular aerobic sequencing batch reactors during start-up and steady state periods. Water Sci Technol. 2010; 62: 1281-1287.

[3] Sanapareddy N, Hamp T J, Gonzalez L C, Hilger H A, Fodor A A, Clinton S M. Molecular Diversity of a North Carolina Wasterwater Treatment Plant as Revealed by Pyrosequencing. Appl Environ Microbiol. 2009; 75: 1688-1696.

[4] McLellan S-L, Huse S M, Muelles-Spitz S R, Andreischeva E N, Sogin M L. Diversity and population structure of sewage-derived microorganism in wastewater treatment plant influent. Environ Microbiol 2010; 12: 378-392.

[5] Bond P L, Rees G N. Microbiological aspects of phosphorus removal in activated sludge systems. In: Seviour R J, Blackall L L, editors. Microbiology of Activated Sludge. Kluwer Academic Publishers, Dordrecht; 1999. p. 227-256.

[6] Jeon C O, Park J M. Microbial communities in activated sludge performing enhanced biological phosphorus removal in a sequencing batch reactor. Water Res. 2003; 37: 2195-2205.

[7] Servior R J, Mino T, Onuki M. The microbiology of biological phosphorus removal in activated sludge systems. FEMS Microbiol Rev. 2003; 27: 99-127.

[8] Jones W, Wilderer P, Schroeder E. Operation of a three-stage SBR system for nitrogen removal from wastewater research. J Water Pollut Control Fed. 1990; 62: $268-274$.

[9] Juretschko S, Timmermann G, Schmid M, Schleifer K-H, Pommerening-Roser A, Koops H-P, Wagner M. Combined molecular and conventional analyses of nitrifying bacterium diversity in activated sludge: Nitrosococcus mobilis and 
Nitrospira-like bacteria as dominant populations. Appl. Environ Microbiol. 1998; 64: 3042-3051.

[10] Beline F, Martinez J, Marol C, Guiraud G. Application of the $15 \mathrm{~N}$ technique to determine the contributions of nitrification and denitrification to the flux of nitrous oxide from aerated pig slurry. Water Res. 2001; 65: 2774-2778.

[11] Coskuner G, Curtis T P. In situ characterization of nitrifiers in an activated sludge plant: detection of Nitrobacter spp. J Appl Microbiol. 2002; 93: 431-437.

[12] Gilbert Y, Bihan Y L, Lessard P. Acetylene blockage technique as a tool to determine denitrification potential of a biomass fixed on an organic media treating wastewater. J Environ Eng Sci. 2006; 5: 437-442.

[13] Otawa K, Asano R, Ohba Y, Sasaki T, Kawamura E, Koyama F, Nakamura S, Nakai Y. Molecular analysis of ammonia-oxidizing bacteria community in intermittent aeration sequencing batch reactors used for animal wastewater treatment. Environ Microbiol. 2006; 8: 1985-1996.

[14]Zheng D. Quantification of Methanosaeta species in anaerobic bioreactors using genus- and species-specific hybridization probes. Microbiol Ecol. 2000; 39: 246262.

[15] Jupraputtasri W, Boonapatcharoen N, Cheevadhanarak S, Chaiprasert P, Tanticharoen M, Techkarnjanaruk S. Use of an alternative Archaea-specific probe for methanogen detection. J Microbiol Methods. 2005; 61: 95-104.

[16] Juretschko S, Loy A, Lehner A, Wagner M. The microbial community composition of a nitrifying-denitrifying activated sludge from an industrial sewage treatment plant analyzed by the full-cycle rRNA approach. Syst Appl Microbiol. 2002; 25: 84-99.

[17]Lens P N, Depoorter M P, Cronenberg C C, Verstraete W H. Sulfate-reducing and methane producing bacteria in aerobic waste-water treatment systems. Water Res. 1995; 29: 871-880.

[18] Rasmussen H, Bruus J H, Keiding K, Nielsen P H. Observation on dewaterability and physical, chemical and microbiological changes in anaerobically stored activated sludge from a nutrient removal plant. Water Res. 1994; 28: 417-425.

[19] Kjeldsen K U, Joulian C, Ingvorsen K. Oxygen tolerance of sulfate-reducing bacteria in activated sludge. Environ Sci Technol 2004; 38: 2038-2043.

[20] Garcia J-L, Patel B K C, Olliver B. Taxonomic, phylogenetic, and ecological diversity of methanogenic Archaea. Anaerobe. 2000; 6: 205-226. 
[21] Schramm A, Santegoeds C M, Nielsen H K, Ploug H, Wagner M, Pribyl M, Wanner J, Amann R, Beer D. On the occurrence of anoxic microniches, denitrification and sulfate reduction in aerated activated sludge. Appl Environ Microbiol. 1999; 65: 4189-4196.

[22] Gray N, Miskin I, Kornilova O, Curtis T, Head I. Occurrence and activity of Archaea in aerated activated sludge wastewater treatment plants. Environ Microbiol. 2002; 4: 158-168.

[23] Rustrian E, Delgenes J, Bernet N, Moletta R. Nitrate reduction in acidogenic reactor: inflence of wastewater $\mathrm{COD} / \mathrm{N}-\mathrm{NO} 3$ ratio on denitrification and acidogenic activity. Environ Technol. 1997;18 :309-315.

[24] Balonch M, Akkunna J, Collier P. Carbon and nitrogen in a granular bed baffled reactor. Environ Technol. 2006;27 : 201-208.

[25] Amann R I, Binder B J, Olson R J, Chisholm S W, Devereux R, Stahl D A. Combination of $16 \mathrm{~S}$ rRNA-targeted oligonucleotide probes with flow cytometry for analyzing mixed microbial populations. Appl Environ Microbiol. 1990; 56: 19191925.

[26] Loy A, Maixner F, Wagner M, Horn M. probeBase - an online resource for rRNAtargeted oligonucleotide probes: new features 2007. Nucleic Acids Res. 2007; 35 : D800-D804.

[27] Daims H, Brühl A, Amann R, Schleifer K-H, Wagner M. The domain specific probe EUB338 is insufficient for the detection of all Bacteria: Development and evaluation of a more comprehensive probe set. Syst. Appl Microbiol. 1999; 22: 434-444.

[28] Alonso J L, Borrás L, Amorós I. Improved in situ hybridization efficiency of nitrifying bacteria with locked-nucleic-acid incorporated DNA probe. ASPD5 IWA Int. Specialised Conference on Microbial Population Dynamics in Biological Wastewater Treatment; 2009 May 24-25; Aalborg, Denmark.

[29]Daims H, Nielsen J L, Nielsen P H, Schleifer K H, Wagner M. In situ characterization of Nitrospira-like nitrite-oxidizing bacteria active in wastewater treatment plants. Appl Environ Microbiol. 2001; 67: 5273-5284.

[30] Wagner M, Rath G, Koops H P, Flood J, Amann R. In situ analysis of nitrifying bacteria in sewage treatment plants. Water Sci Technol. 1996; 34: 237-244.

[31] Crocetti G R, Hugenholtz P, Bond P I, Schuler A, Keller J, Jenkins D, Blackall L L. Identification of Polyphosphate-Accumulating Organisms and Design of 
16rRNA-Directed Probes for Their Detection and Quantification. Appl Environ Microbiol. 2000; 66: 1175-1182.

[32] Crocetti G R, Banfield J F, Keller J, Bond P L, Blackall L L. Glycogen accumulating organisms in laboratory-scale and full-scale wastewater treatment processes. Microbiology. 2002; 148: 3353-3364.

[33] Kong Y H, Ong S L, Ng W J, Liu W T. Diversity and distribution of a deeply branched novel Proteobacteria group found in anaerobic-aerobic activated sludge processes. Environ Microbiol. 2002; 4: 753-757.

[34] Wong M T, Tan F M, Ng W J, Liu WT. Identification and occurrence of tetradforming Alphaproteobacteria in anaerobic-aerobic activated sludge processes. Microbiology. 2004; 150: 3741-3748.

[35] Meyer R L, Saunders A M, Blackall L L. Putative glycogen accumulating organisms belonging to Alphaproteobacteria identified through rRNA-based stable isotope probing. Microbiology. 2006; 152: 419-429.

[36] Eller G, Stubner S, Frenzel P. Group-specific 16S rRNA targeted probes for the detection of type I and type II methanotrophs by fluorescence in situ hybridisation. FEMS Microbiol Lett. 2001; 198: 91-97.

[37]Rabus R, Wilkes H, Schramm A, Harms G, Behrends A, Amann R, Widdel F. Anaerobic utilization of alkylbenzenes and n-alkanes from crude oil in an enrichment culture of denitrifying bacteria affiliating with the beta-subclass of Proteobacteria. Environ Microbiol. 1999; 1:145-157.

[38] Neef A, Zaglauer A, Meier H, Amann R, Lemmer H, Schleifer K-H. Population analysis in a denitrifying sand filter: conventional and in situ identification of Paracoccus spp. in methanol-fed biofilms. Appl Environ Microbiol. 1996; 62: 4329-4339.

[39] Fernandez N, Sierra-Alvarez R, Field J A, Amils R, Sanz J L. Microbial population dynamics in a chemolithotrophic denitrification reactor. Chemosphere 2008; 70 : 462-474.

[40] Devereux R, Kane M D, Winfrey J, Stahl D A. Genus- and group-specific hybridization probes for determinative and environmental studies of sulfatereducing bacteria. Syst Appl Microbiol. 1992; 15: 601-609.

[41]Fukui M, Teske A, Ammus B, Muyzer G, Widdel F. Physiology, Phylogenetic relationships, and ecology of filamentous sulfate-reducing bacteria (genus Desulfonema). Arch Microbiol. 1999; 172: 193-203. 
[42] Hristova K R, Mau M, Zheng D, Aminov R I, Mackie R I, Gaskins H R, Raskin L. Desulfotomaculum genus- and subgenus-specific 16S rRNA hybridization probes for environmental studies. Environ Microbiol. 2000; 2: 143-159.

[43] Rabus R, Fukui M, Wilkes H, Iddel F. Degradativ capacities and 16s rRNATargeted Whole-cell Hydridization of Sulfate-Reducing Bacteria in an Anaerobic Enrichment culture Utilizing Alkylbenzenes from Crude oil. Appl Environ Microbiol. 1996; 62; 3605-3613.

[44] Stahl D A, Amann R. Development and application of nucleic acid probes. In Stackebrandt E, Goodfellow M, editor. Nucleic acid techniques in bacterial systematic. New York: John Wiley \& Sons; 1991. p. 205-248.

[45] Crocetti G, Murto M, Björnsson L. An update and optimisation of oligonucleotide probes tarjeting methanogenic Archaea for use in fluorescence in situ Hybridisation (FISH). J Microbiol methods. 2006; 65: 194-201.

[46] Raskin L, Stromley J M, Rittmann B E, Stahl D A. Group-specific 16S rRNA hybridization probes to describe natural communities of methanogens. Appl Environ Microbiol. 1994; 60: 1232-1240.

[47] Borrás L. Técnicas microbiológicas aplicadas a la identificación y cuantificación de microorganismos presentes en sistemas EBPR [Microbiological techniques applied to the identification and quantification of microorganisms in EBPR systems]. Universidad Politécnica de Valencia; 2008.

[48] Carvalho G, Oehmen A, Albuquerque MG, Reis MA. The relationship between mixed microbial culture composition and PHA production performance from fermented molasses. N Biotechnol. 2013. http://dx.doi.org/10.1016/j.nbt.2013.08.010

[49] Silva AF, Carvalho G, Oehmen A, Lousada-Ferreira M, van Nieuwenhuijzen A, Reis MAM, Crespo MTB. Microbial population analysis of nutrient removalrelated organisms in membrane bioreactors. Appl Microbiol Biotechnol. 2012; 93: 2171-2180.

[50]Zhang Tian C. Development of Sulfur-Limestone autotrophic denitrification processes for Treatment of nitrate-contaminated groundwater in small communities. Ed.: Midwest Technology Assistance Center. Champaign, Ilinois; 2004.

[51] Lee H, Keun Y, Choi E, Woo J. Bacterial Community and Biological Nitrate Removal: Comparisons of Autotrophic and Heterotrophic Reactor For Denitrification with Raw Sewage. J. Microbiol Biotechnol. 2008; 18: 1826-1835. 
[52] Morgan-Sagastume F, Nielsen J L, Halkjær P. Substrate-dependent denitrification of abundant probe-defined denitrifying bacteria in activated sludge. FEMS Microbiol Ecol. 2008; 66: 447-461.

[53] Thomsen T R, Kong Y, Nielsen P H. Ecophysiology of dominant denitrifying bacteria in activated sludge. FEMS Microbiol Ecol. 2007; 60: 370-382.

[54] Baker S C, Ferguson S J., Ludwig B M, Dudley P, Richter O-M, van Spanning R J M. Molecular Genetics of the Genus Paracoccus: Metabolically Versatile Bacteria with Bioenergetic Flexibility. Microbiol Mol Biol Rev. 1998; 62: 1046-1078.

[55] Baumann B, Snozzi M, Alexander J, Zehder B, Rodolf J, van der Meer J R. Dynamics of Denitrification Activity of Paracoccus denitrificans in Continuous Culture during Aerobic-Anaerobic Changes. J Bacteriol. 1996; 178: 4367-4374.

[56] Kelly D P, Wood A P. Confirmation of Thiobacillus denitrificans as a species of the genus Thiobacillus, in the $\beta$-subclass of the Proteobacteria, wit strain NCIMB 9548 as the type stain. Int J Syst Evol Microbiol. 2000; 50: 547-550.

[57] Beller H, Chain P, Letain T, Chakicherla A, Larimer F, Richardson P, Coleman M, Wood A, Kelly D P. The Genome sequence of the obligately chemolithoautotrophic, facultatively anaerobic bacterium Thiobacillus denitrificans. J Bacteriol. 2006; 188: 1473-1488.

[58] Akunna J C, Biceau C, Moletta R. Denitrification in anaerobic digesters: possibilities and influence of wastewater COD/N-NOx ratio. Env Technol. 1992; 13: $825-836$.

[59] Jørgensen K S, Tiedje M T. Survival of Denitrifiers in Nitrate-Free, Anaerobic Environments. Appl. Environ Microbiol. 1993; 59: 3297-3305.

[60]Baumgartner L, Reid R, Dupraz C, Decho A, Buckley D, Spear I, Przekop K, Visscher P. Sulfate reducing bacteria in microbial mats: changing paradigms, new discoveries. Sediment Geol. 2006; 185: 131-145.

[61] Icgen B, Moosa S, Harrison S T L. A Study of the Relative Dominance of Selected Anaerobic Sulfate-Reducing Bacteria in a Continuous Bioreactor by Fluorescence in Situ Hybridization. Microbiol Ecol. 2006; 53: 43-52.

[62] Canfield D E, Des Marais D J. Aerobic sulfate reduction in microbial mats. Science 1991; 251: 1471-1473.

[63] Jørgensen B B, Bak F. Pathways and microbiology of thiosulfate transformations and sulfate reduction in a marine sediment (Kattegat, Denmark). Appl Environ Microbiol. 1991; 57: 847-856. 
[64] Marschall C, Frenzel P, Cypionka H. Influence of oxygen on sulfate reduction and growth of sulfate-reducing bacteria. Arch Microbiol. 1993; 159: 168-173.

[65] Teske A, Wawer C, Muyzer G, Ramsing N B. Distribution of sulfate-reducing bacteria in a stratified fjord (Mariager Fjord, Denmark) as evaluated by mostprobable-number counts and denaturing gradient gel electrophoresis of PCRamplified ribosomal DNA fragments. Appl Environ Microbiol. 1996; 62: 14051415.

[66] Santegoeds C M, Ferdelman T G, Muyzer G, de Beer D. Structure and functional dynamics of sulfate-reducing populations in bacterial biofilms. Appl Environ Microbiol. 1998; 64: 3731-3739.

[67] Okabe S, Itoh T, Satoh H, Watanabe Y. Analyses of Spatial Distributions of Sulfate-Reducing Bacteria and Their Activity in Aerobic Wastewater Biofilms. Appl Environ Microbiol. 1999; 65: 115107-5116.

[68] Macaire H, Guiot S. Fronteras en Biotecnología y Bioingeniría. Degradación de Pentaclorofenol mediante un proceso Aerobio/Anaerobio simultáneo: una Nueva Tecnología para el Tratamiento de Aguas Residuales. [Frontiers in Biotechnology and Bioingeniery. Degradation of Pentachlorophenol by an Aerobic/Anaerobic concurrent process: A New Technology for Wastewater Treatment]. Sociedad Méxicana de Biotecnología y Bioingeniería, A. C. 1996. p.317-324.

[69] Anzola M, Oliveira A, Zaiat M. Specific Methanogenic activity in an AnaerobicAerobic reactor applied to the treatment of Domestic Residual Water. Interciencia. 2008; 33: 284-289. 
Table 1. Probes used in this study

\begin{tabular}{|c|c|c|c|c|}
\hline Probe & Sequence & Organism & \%FA & Ref. \\
\hline EUB338 & GCTGCCTCCCGTAGGAGT & Most bacteria & $0-50$ & [25] \\
\hline EUB338 II & GCAGCCACCCGTAGGTGT & Planctomycetales & $0-50$ & [27] \\
\hline EUB338 III & GCTGCCACCCGTAGGTGT & Verrucomicrobiales & $0-50$ & [27] \\
\hline NSO1225LNA & CGCCATTGTATTACGTGTGA & Betaproteobacterial ammonia-oxidizing bacteria & 45 & [28] \\
\hline Ntspa712 & CGCCTTCGCCACCGGCCTTCC & Most members of Phylum Nitrospirae & 50 & [29] \\
\hline cNtspa 712 & CGCCTTCGCCACCGGTGTTCC & Competitor of probe Ntspa712 & 50 & [29] \\
\hline NIT3 & CCTGTGCTCCATGCTCCG & Nitrobacter spp. & 40 & [30] \\
\hline cNIT3 & CCTGTGCTCCAGGCTCCG & Competitor of probe NIT3 & 40 & [30] \\
\hline PAO462 & CCGTCATCTACWCAGGGTATTAAC & Candidatus Accumulibacter phospatis & 35 & [31] \\
\hline PAO651 & CCCTCTGCCAAACTCCAG & $\begin{array}{l}\text { Most members of Candidatus Accumulibacter } \\
\text { cluster }\end{array}$ & 35 & [31] \\
\hline PAO846 & CTTAGCTACGGCACTAAAAGG & Candidatus Accumulibacter phospatis & 35 & [31] \\
\hline GAOQ431 & TCCCCGCCTAAAGGGCTT & Candidatus Competibacter phospatis & 35 & [32] \\
\hline GAOQ989 & TTCCCCGGATGTCAAGGC & Candidatus Competibacter phospatis & 35 & {$[32]$} \\
\hline GB & CGATCCTCTAGCCCACT & Novel gammaproteobacteria group & $35-70$ & {$[33]$} \\
\hline TFO_DF218 & GAAGCCTTTGCCCCTCAG & Alphaproteobacteria Defluviicoccus (cluster 1) & $25-35$ & {$[34]$} \\
\hline TFO_DF618 & GCCTCACTTGTCTAACCG & Alphaproteobacteria Defluviicoccus (cluster 1) & $25-35$ & {$[34]$} \\
\hline DF988 & GATACGACGCCCATGTCAAGGG & Alphaproteobacteria Defluviicoccus (cluster 1) & 35 & [35] \\
\hline DF1020 & CCGGCCGAACCGACTCCC & Alphaproteobacteria Defluviicoccus (cluster 1) & 35 & [35] \\
\hline H966 & CTGGTAAGGGTTCTGCGCGTTGC & Helper probe for DF988 & 35 & [35] \\
\hline H1038 & $\begin{array}{l}\text { AGCAGCCATGCAGCACCTGTATGG } \\
\text { CGT }\end{array}$ & Helper probe for DF988 & 35 & [35] \\
\hline Ma464 & TTATCCAGGTACCGTCATTA & $\begin{array}{l}\text { Type II methanotrophs ( } \alpha \text {-proteobacteria } \\
\text { methylocystaceae) }\end{array}$ & 20 & [36] \\
\hline Mg84 & CCACTCGTCAGCGCCCGA & $\begin{array}{l}\text { Type I methanotrophs ( } \gamma \text {-proteobacteria } \\
\text { methylococcaceae) }\end{array}$ & 20 & [36] \\
\hline AT1458 & GAATCTCACCGTGGTAAGCGC & $\begin{array}{l}\text { Azoarcus-Thauera cluster within } \\
\text { Betaproteobacteria }\end{array}$ & 50 & [37] \\
\hline PAR651 & ACCTCTCTCGAACTCCAG & Genus Paracoccus & 40 & [38] \\
\hline TBD1419 & ACTTCTGCCAGATTCCAC & Thiobacillus denitrificans & 50 & [39] \\
\hline DSV687 & TACGGATTTCACTCCT & $\begin{array}{l}\text { Most Desulfovibrionales (excluding Lawsonia) } \\
\text { and many Desulfuromonales }\end{array}$ & 15 & [40] \\
\hline Dsb804 & CAACGTTTACTGCGTGGA & Some desulfobacteraceae & 10 & [40] \\
\hline DNMA657 & TTCCGCTTCCCTCTCCCATA & Some desulfonema & 30 & [41] \\
\hline DBB660 & GAATTCCACTTTCСССТCTG & Some desulfobulbus & 60 & [40] \\
\hline $\operatorname{Dtm} 230$ & TAATGGGACGCGGACCCA & $\begin{array}{l}\text { Many desulfotomaculum cluster } 1 \text { and other } \\
\text { firmicutes }\end{array}$ & 10 & [42] \\
\hline SRB385 & CGGCGTCGCTGCGTCAGG & Most desulfovibrionales and other bacteria & 35 & [25] \\
\hline SRB385Db & CGGCGTTGCTGCGTCAGG & $\begin{array}{l}\text { Desulfobacterales, Desulfuromonales, } \\
\text { Syntrophobacterales, Myxococcales, and other } \\
\text { bacteria }\end{array}$ & 30 & [43] \\
\hline
\end{tabular}




$\left.\begin{array}{|lllrc}\text { ARCH915 } & \text { GTGCTCCCCCGCCAATTCCT } & \text { Archaea } & 35 & {[44]} \\ \text { MSMX860 } & \text { GGCTCGCTTCACGGCTTCCCT } & \begin{array}{l}\text { Methanosarcinales (all Methanosarcina and } \\ \text { Methanosaeta) }\end{array} & 45 & {[45]} \\ \text { MG1200b } & \text { CRGATAATTCGGGGCATGCTG } & \text { Most methanomicrobiales } & 20 & {[45]} \\ \text { MB311 } & \text { ACCTTGTCTCAGGTTCCATCTCC } & \text { Methanobacterales } & 30 & {[45]} \\ \text { MC504 } & \text { GGCTGCTGGCACCGGACTTGCCCA } & \text { Methanocaldococcaceae } & 55 & {[45]} \\ \text { cMC504 } & \text { GGCTGCTGGCACCGAACTTGCCCA } & \text { Competitor of probe MC504 } & 55 & {[45]} \\ \text { MC1109 } & \text { GCAACATAGGGCACGGGTCT } & \text { Methanococcaceae } & 45 & {[46]}\end{array}\right]$


Table 2. Microbial diversity in activated sludge and anaerobic digester

\begin{tabular}{|c|c|c|c|c|}
\hline Probe & Organism & $\begin{array}{c}\text { Group } \\
\text { (phenotype) }\end{array}$ & $\begin{array}{l}\text { Aerobic } \\
\text { reactor }\end{array}$ & $\begin{array}{c}\text { Anaerobic } \\
\text { digester }\end{array}$ \\
\hline NSO1225LNA & Ammonio-oxidizing & $\mathrm{AOB}$ & $7 \%( \pm 1)$ & $\mathrm{ND}^{*}$ \\
\hline Ntspa712 & Nitrospirae phylum & NOB & $2 \%( \pm 1)$ & ND \\
\hline NIT3 & Nitrobacter & NOB & ND & ND \\
\hline $\begin{array}{l}\text { PAO mix } \\
\text { (PAO462,PAO651, } \\
\text { PAO846) }\end{array}$ & $\begin{array}{l}\text { Candidatus accumulibacter } \\
\text { phosphatis }\end{array}$ & $\mathrm{PAO}$ & $2 \%( \pm 1)$ & ND \\
\hline $\begin{array}{l}\text { GAO mix } \\
\text { (GAOQ431, } \\
\text { GAOQ989,GB) }\end{array}$ & $\begin{array}{l}\text { Candidatus competibacter } \\
\text { phosphatis }\end{array}$ & GAO & ND & ND \\
\hline $\begin{array}{l}\text { DEF mix 1 } \\
\text { (TFO_DF218, } \\
\text { TFO_DF618) }\end{array}$ & Defluvicoccus cluster 1 & GAO & ND & ND \\
\hline $\begin{array}{l}\text { DEF mix2 (DF988, } \\
\text { DF1020) }\end{array}$ & Defluvicoccus cluster 2 & GAO & $4 \%( \pm 2)$ & ND \\
\hline Ma464 & Methylocystaceae type 2 & $\begin{array}{l}\text { Methanotrophic } \\
\text { bacteria }\end{array}$ & $1 \%( \pm 1)$ & ND \\
\hline Mg84 & Methylococcaceae type 1 & $\begin{array}{l}\text { Methanotrophic } \\
\text { bacteria }\end{array}$ & ND & ND \\
\hline AT1458 & Azoarcus-Thauera cluster & $\begin{array}{l}\text { Denitrifying } \\
\text { bacteria }\end{array}$ & $15 \%( \pm 1)$ & $3 \%( \pm 1)$ \\
\hline PAR651 & Paracoccus & $\begin{array}{l}\text { Denitrifying } \\
\text { bacteria }\end{array}$ & $4 \%( \pm 1)$ & $3 \%( \pm 2)$ \\
\hline TBD1419 & Thiobacillus denitrificans & $\begin{array}{l}\text { Denitrifying } \\
\text { bacteria }\end{array}$ & ND & $4 \%( \pm 2)$ \\
\hline DSV687 & $\begin{array}{l}\text { Desulfovibrio, Desulfomonas, } \\
\text { Desulforomonas, } \\
\text { Desulfomicrobium }\end{array}$ & SRB & ND & ND \\
\hline Dsb804 & some Desulfobacteraceae & SRB & ND & ND \\
\hline DNMA657 & some Desulfonema & SRB & $8 \%( \pm 1)$ & $4 \%( \pm 1)$ \\
\hline DBB660 & some Desulfobulbus & SRB & ND & ND \\
\hline $\operatorname{Dtm} 230$ & many Desulfotomaculum & SRB & ND & ND \\
\hline SRB385 & $\begin{array}{l}\text { most Desulfovibrionales and } \\
\text { other bacteria }\end{array}$ & SRB & $12 \%( \pm 1)$ & $14 \%( \pm 2)$ \\
\hline $\mathrm{SRB} 385 \mathrm{Db}$ & Desulfobacteraceae & SRB & $15 \%( \pm 3)$ & $6 \%( \pm 2)$ \\
\hline MSMX860 & Methanosarciales & $\begin{array}{l}\text { methanogenic } \\
\text { archaea }\end{array}$ & ND & $14 \%( \pm 2)$ \\
\hline MG1200b & Methanomicrobiales & methanogenic & $6 \%( \pm 1)$ & $8 \%( \pm 2)$ \\
\hline
\end{tabular}




\begin{tabular}{|c|c|c|c|c|}
\hline & & archaea & & \\
\hline MB311 & Mathenobacterales & $\begin{array}{l}\text { methanogenic } \\
\text { archaea }\end{array}$ & $5 \%( \pm 1)$ & $8 \%( \pm 2)$ \\
\hline MC504 & Methanocaldococcaceae & $\begin{array}{c}\text { methanogenic } \\
\text { archaea }\end{array}$ & ND & ND \\
\hline MC1109 & Mathanococcales & $\begin{array}{c}\text { methanogenic } \\
\text { archaea }\end{array}$ & ND & ND \\
\hline
\end{tabular}

*ND: Not detected

AOB: Ammonia-oxidizing bacteria

NOB: Nitrite-oxidizing bacteria

PAO: Polyphosphate accumulating organisms

GAO: Glycogen accumulating organisms

SRB: Sulfate reducing bacteria 
Figure 1. Diversity of microbes found in aerobic reactor (a) and anaerobic digester (b). 


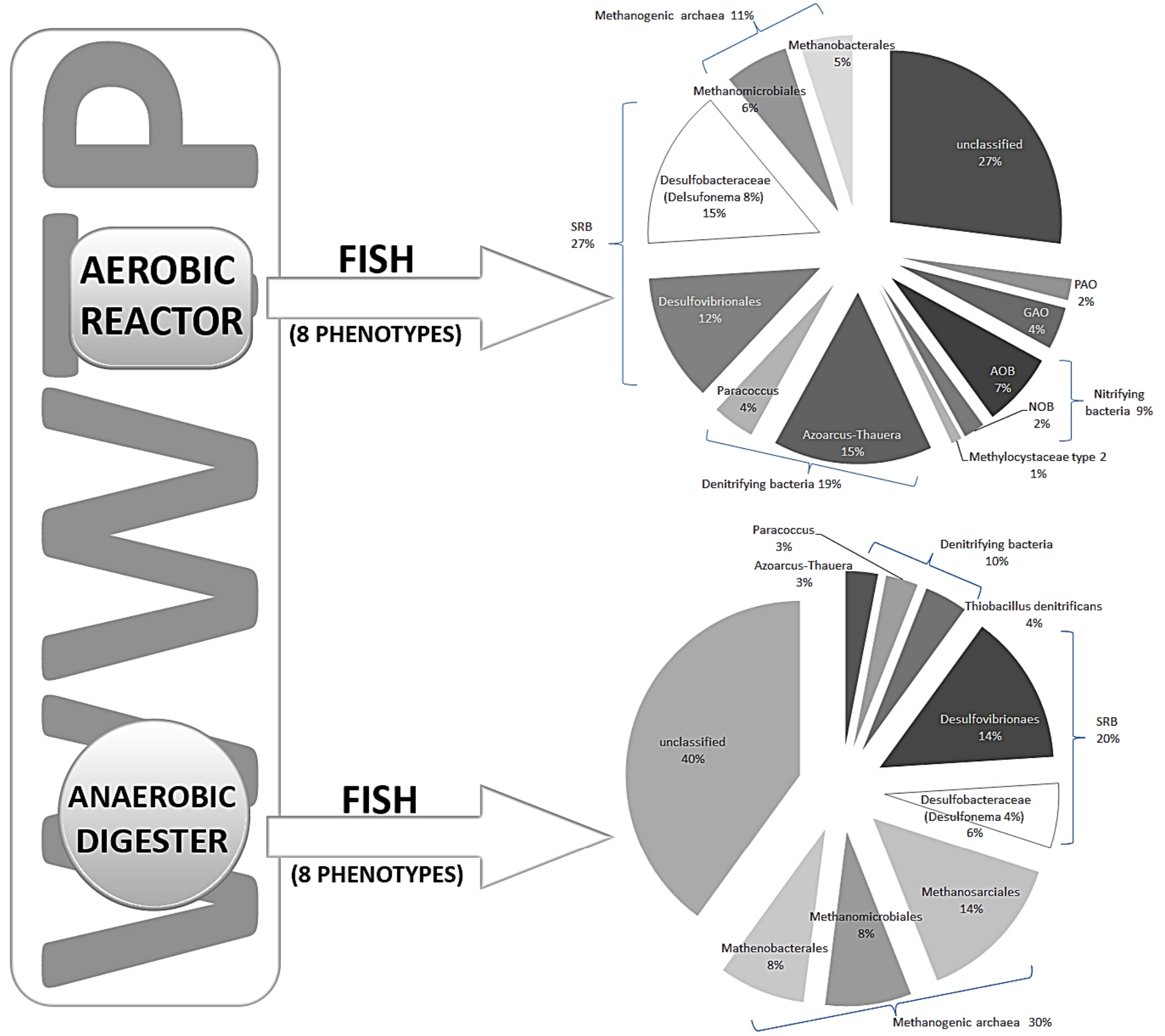

